\title{
PERSEPSI GURU PENJAS TERHADAP KOMPETENSI MAHASISWA MAGANG 2 PRODI PENJAS FKIP UNIB DI SMP NEGERI KOTA BENGKULU TAHUN 2018
}

\author{
Rudi Hartono \\ Email: Rudi.hartono683@yahoo.co.id \\ Universitas Bengkulu \\ Dian Pujianto \\ Universitas Bengkulu \\ Arwin \\ Universitas Bengkulu
}

\begin{abstract}
ABSTRAK
Penelitian ini bertujuan untuk mengetahui persepsi Guru Penjas terhadap kompetensi mahasiswa magang 2 Prodi Penjas FKIP UNIB di SMP Negeri Kota Bengkulu tahun 2018. Dalam penelitian ini mengunakan, metode survei. Instrumen yang digunakan adalah angket. Penyusunan instrumen menggunakan langkah-langkah: mendefinisikan konstruk, minyidik faktor, dan menyusun butir-butir pernyataan. Subjek dalam penelitian ini adalah 20 guru penjas dari 8 SMP Negeri di Kota Bengkulu yang pada tahun 2018 sekolah tempat mengajarnya digunakan untuk tempat magang 2 mahasiswa Prodi Penjas FKIP UNIB. Teknik analisis data menggunakan analisis deskriptif kualitatif dengan persentase yang dikategorikan menjadi 5 kategori yaitu sangat tinggi, tinggi, sedang, rendah, sangat rendah. Hasil penelitian menunjukkan bahwa persepsi Guru Penjas terhadap kompetensi mahasiswa magang 2 Prodi Penjas FKIP UNIB di SMP Negeri Kota Bengkulu tahun 2018 yaitu (a) kompetensi pedagogik dalam kategori tinggi, (b) kompetensi kepribadian dalam kategori tinggi dan rendah, (c) kompetensi sosial dalam kategori sedang, (d) kompetensi Profesional dalam kategori sedang. Secara keseluruhan masuk dalam kategori sedang yakni sebesar $35 \%$. Sedangkan sisanya yakni $15 \%$ masuk dalam kategori sangat rendah, $15 \%$ masuk dalam kategori rendah, 25\% masuk dalam kategori tinggi, 10\% masuk dalam kategori sangat tinggi.
\end{abstract}

Kata kunci : Persepsi, Kompetensi, Guru Penjas, Mahasiswa.

\begin{abstract}
This study aims to determine the perception of physical educator on the conpetency of students in internship 2 in Physical education Study Program FKIP UNIB in Bengkulu City Public Junior High school in 2018. In this study, the suvery method was used. The instrument used was a questionnaire. The preparation of instruments uses steps: defining constructs, investigating factors, and compiling items of statements. The subjects in the study were 20 physical educator from 8 public junior high school in the city of Bengkulu which in 2018 the school where they taught was used as a place of internship for 2 students of the National Education Study Program FKIP UNIB. Data analysis techniques used qualitative descriptive analysis with the percentage categorized into 5 categories namely very high, high, medium, low, very low. The results of the study showed that the perception of physical educator on the competency of student internship 2 in the Penjas Study Program FKIP UNIB in Bengkulu
\end{abstract}


City Middle school in 2018 was overall moderate. In detail, as many as $10 \%$ very high, $25 \%$ high, $35 \%$ moderate, $15 \%$ low, $15 \%$ very low.

Keywords: perception, competence, Physical Educator, college student

\section{PENDAHULUAN}

Pendidikan merupakan upaya normatif yang mengacu pada nilainilai mulia, yang menjadi bagian dari kehidupan bangsa, yang dengannya nilai tersebut dapat dilanjutkan melalui transfer pendidikan baik aspek pengetahuan (kognitif), sikap (afektif), maupun keterampilan (psikomotor). Pendidikan membimbing manusia menjadi manusiawi yang semakin dewasa secara intelektual, moral dan sosial, dalam konteks ini pendidikan merupakan pemelihara budaya. Pendidikan mempunyai peranan penting, disadari atau tidak pendidikan akan menghasilkan manusia yang menghargai harkat dan martabatnya sendiri. Pendidikan bermaksud mengembangkan segala potensi yang ada didalam individu tersebut. Perkembangan potensi tersebut tidak terlepas dari peran guru.

Berdasarkan Undang-Undang nomor 14 tahun 2005 disebutkan 4 kompetensi guru yang meliputi: kompetensi pedagogik, kompetensi kepribadian, kompetensi profesional, dan kompetensi sosial. Secara akademik, guru dituntut untuk mampu menampilkan kompetensi tertentu sebagai konsekuensi logis dari perubahan yang terjadi di tengah-tengah masyarakat dewasa ini.

Mengingat pentingnya peranan guru dalam upaya peningkatan mutu pendidikan maka Universitas Bengkulu (UNIB) sebagai salah satu lembaga pendidikan yang mencetak calon guru, telah mengarahkan mahasiswanya agar memiliki pengalaman dalam mengajar dan mengacu pada kompetensi yang dibutuhkan dalam mengajar dilapangan. Dan salah satu cara dengan membekali para mahasiswa dengan seperangkat kompetensi bagi para calon guru melalui magang 2 yaitu Praktek Pengalaman Lapangan (PPL).

Sampai saat ini sebatas pengamatan peneliti yang pernah melaksanakan PPL di sekolah peneliti menemukan kasus-kasus yang dialami mahasiswa Penjas, salah satunya ialah perbedaan cara penyampaian materi antara mahasiswa dan guru pembimbing saat melaksanakan PPL, kemudian mahasiswa Penjas pulang lebih awal dari jam yang telah ditentukan oleh sekolah, terkadang juga datang terlambat saat mengajar, kurangnya persiapan perangkat pembelajaran dan penerapan variasi model mengajar dalam pembelajaran, saat pelaksanaan PPL mahasiswa kurang bisa mengelola kelas pada saat pengajaran teori, ada yang kurang bisa dalam mengevaluasi hasil belajar peserta didiknya, bahkan adanya masalah dengan orang tua murid karena tindakan yang kurang terpuji dari mahasiswa.

Sebagaimana telah diuraikan di atas, sejauh ini belum ada yang mengkaji permasalahan tersebut. Sehingga dalam penelitian ini mengambil judul "Persepsi Guru Penjas Terhadap kompetensi Mahasiswa Magang 2 Program Studi 
Penjas FKIP UNIB di SMP Negeri Kota Bengkulu Tahun 2018."

\section{METODE}

Penelitian ini merupakan penelitian deskriptif kualitatif yang ingin menggambarkan apa adanya tentang persepsi guru penjas terhadap mahasiswa magang 2 prodi Penjas FKIP UNIB di SMP Negeri Kota Bengkulu Tahun 2018. Data yang diperlukan diperoleh berdasar atas perumusan masalah. Metode yang digunakan adalah survei dan teknik pengambilan datanya dengan angket. Survei adalah suatu proses pengumpulan data (satu atau beberapa variabel) dari suatu anggota populasi. Menurut Sugiyono (2013: 193), bahwa kuesioner atau angket merupakan teknik pengumpulan data yang dilakukan dengan cara memberi seperangkat pertanyaan atau penyataan tertulis kepada responden untuk dijawabnya. Skor yang diperoleh dari angket kemudian dianalisis dengan analisis deskriptif yang dituangkan dalam bentuk persentase

Menurut Suharsimi Arikunto (2010 : 188) subjek penelitian adalah subjek yang dituju untuk diteliti oleh peneliti. Subjek penelitian adalah subjek yang memnjadi pusat perhatian atau sasaran peneliti. Subjek dalam penelitian ini adalah guru penjas di SMP Negeri Kota Bengkulu yang menjadi lokasi magang 2/PPL FKIP UNIB periode tahun 2018.

Objek penelitian merupakan hal yang menjadi titik perhatian dari suatu penelitian. Objek dalam penelitian ini adalah kompetensi mahasiswa magang 2/PPL FKIP UNIB periode tahun 2018.

Dalam penelitian ini teknik pengumpulan data adalah dengan survei, penulis menggunakan jenis angket tetutup.. Angket tertutup adalah angket yang sudah disediakan jawabannya sehingga responden tinggal memilih (Suharsimi Arikunto, 2002: 129).

\section{HASIL DAN PEMBAHASAN}

HASIL

Tabel 1. Data penelitian kompetensi pedagogik

\begin{tabular}{c|c|c|c} 
no & kategori & frekuensi & Persentase \\
\hline 1 & $\begin{array}{c}\text { Sangat } \\
\text { Tinggi }\end{array}$ & 0 & $0 \%$ \\
\hline 2 & Tinggi & 8 & $40 \%$ \\
\hline 3 & Sedang & 7 & $35 \%$ \\
\hline 4 & Rendah & 4 & $20 \%$ \\
\hline 5 & $\begin{array}{c}\text { Sangat } \\
\text { Rendah }\end{array}$ & 1 & $5 \%$ \\
\hline \multicolumn{2}{c}{ Jumlah } & 20 & $100 \%$
\end{tabular}

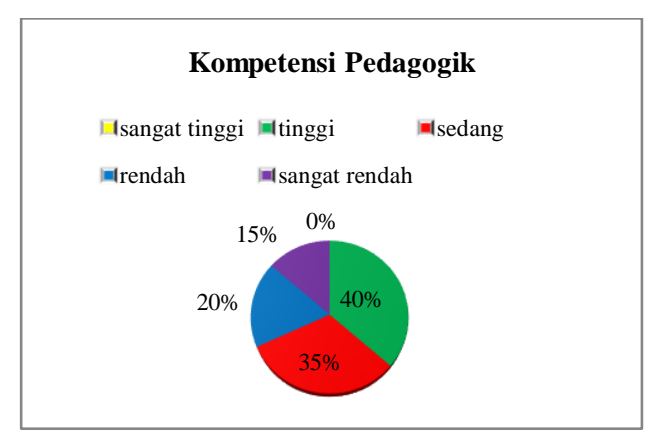

Gambar 2.

\section{Persentase penelitian kompetensi} pedagogik

Dari tabel dan gambar di atas diperoleh persepsi guru penjas terhadap Kompetensi Mahasiswa Magang 2 Program Studi Penjas FKIP UNIB di SMP Negeri Kota Bengkulu tahun 2018 berdasarkan kompetensi pedagogik yaitu sebanyak 1 guru (5\%) 
dalam kategori sangat rendah, 4 guru (20\%) dalam kategori rendah, 7 guru (35\%) dalam kategori sedang, 8 guru (40\%) dalam kategori tinggi, dan 0 guru (00 dalam kategori sangat tinggi.

\section{Tabel 2. Data Penelitian} kompetensi kepribadian.

\begin{tabular}{c|c|c|c} 
No & kategori & Frekuensi & Persentase \\
\hline 1 & $\begin{array}{c}\text { Sangat } \\
\text { Tinggi }\end{array}$ & 0 & $0 \%$ \\
\hline 2 & Tinggi & 7 & $35 \%$ \\
\hline 3 & Sedang & 5 & $25 \%$ \\
\hline 4 & Rendah & 7 & $35 \%$ \\
\hline 5 & $\begin{array}{c}\text { Sangat } \\
\text { Rendah }\end{array}$ & 1 & $5 \%$ \\
\hline \multicolumn{2}{c}{ jumlah } & 20 & $100 \%$
\end{tabular}

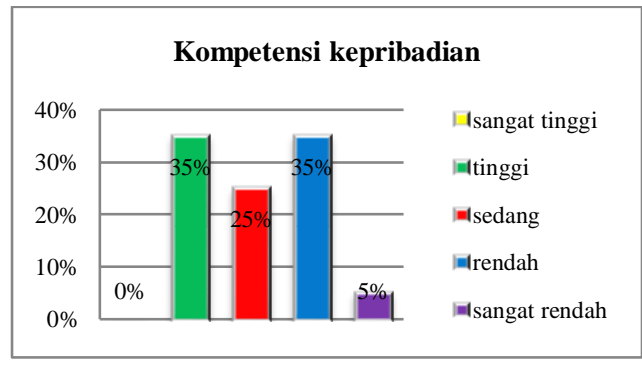

Gambar 3.

Persentase Penelitian kompetensi kepribadian

Dari tabel dan gambar di atas diperoleh persepsi guru penjas terhadap Kompetensi Mahasiswa Magang 2 Program Studi Penjas FKIP UNIB di SMP Negeri Kota Bengkulu tahun 2018 berdasarkan kompetensi kepribadian yaitu sebanyak 1 guru (5\%) dalam kategori sangat rendah, 7 guru (20\%) dalam kategori rendah, 5 guru (35\%) dalam kategori sedang, 7 guru $(35 \%)$ dalam kategori tinggi, dan 0 guru $(00 \%)$ dalam kategori sangat tinggi.
Tabel 3. Data penelitian kompetensi sosial

\begin{tabular}{c|c|c|c} 
No & kategori & frekuensi & Persentase \\
\hline 1 & $\begin{array}{c}\text { Sangat } \\
\text { Tinggi }\end{array}$ & 0 & $0 \%$ \\
\hline 2 & Tinggi & 7 & $35 \%$ \\
\hline 3 & Sedang & 8 & $40 \%$ \\
\hline 4 & Rendah & 3 & $15 \%$ \\
\hline 5 & $\begin{array}{c}\text { Sangat } \\
\text { Rendah }\end{array}$ & 2 & $10 \%$ \\
\hline \multicolumn{2}{c}{ jumlah } & 20 & $100 \%$
\end{tabular}

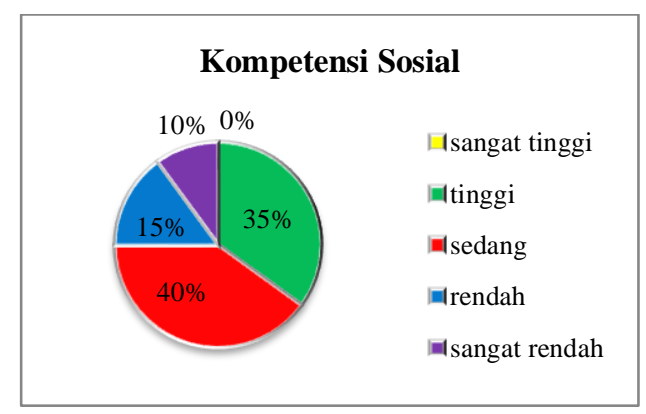

Gambar 4

Persentase Penelitian kompetensi sosial

Dari tabel dan gambar di atas diperoleh persepsi guru penjas terhadap Kompetensi Mahasiswa Magang 2 Program Studi Penjas FKIP UNIB di SMP Negeri Kota Bengkulu tahun 2018 berdasarkan kompetensi sosial yaitu sebanyak 2 guru (10\%) dalam kategori sangat rendah, 3 guru (15\%) dalam kategori rendah, 8 guru (40\%) dalam kategori sedang, 7 guru (35\%) dalam kategori tinggi, dan 0 guru $(00 \%)$ dalam kategori sangat tinggi.

Tabel 4. Data Penelitian berdasarkan faktor profesional

\begin{tabular}{c|c|c|c} 
No & kategori & rekuensi & Persentase \\
\hline 1 & $\begin{array}{c}\text { Sangat } \\
\text { Tinggi }\end{array}$ & 0 & $0 \%$ \\
\hline 2 & Tinggi & 6 & $30 \%$ \\
\hline 3 & Sedang & 10 & $50 \%$ \\
\hline 4 & Rendah & 2 & $10 \%$ \\
\hline
\end{tabular}




\begin{tabular}{c|c|c|c}
\hline 5 & $\begin{array}{c}\text { Sangat } \\
\text { Rendah }\end{array}$ & 2 & $10 \%$ \\
\hline \multicolumn{2}{c}{ jumlah } & 20 & $100 \%$
\end{tabular}

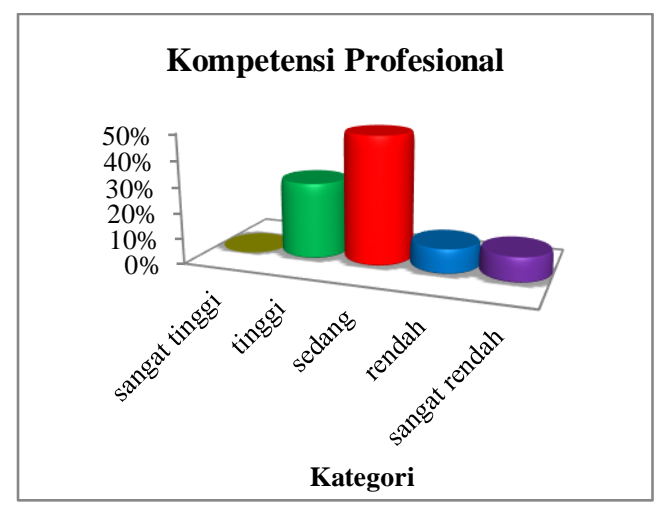

Gambar 5

\section{Persentase Penelitian kompetensi profesional}

Dari tabel dan gambar di atas diperoleh persepsi guru penjas terhadap Kompetensi Mahasiswa Magang 2 Program Studi Penjas FKIP UNIB di SMP Negeri Kota Bengkulu tahun 2018 berdasarkan kompetensi profesional yaitu sebanyak 2 guru (10\%) dalam kategori sangat rendah, 2 guru (10\%) dalam kategori rendah, 10 guru (50\%) dalam kategori sedang, 6 guru (30\%) dalam kategori tinggi, dan 0 guru $(00 \%)$ dalam kategori sangat tinggi.

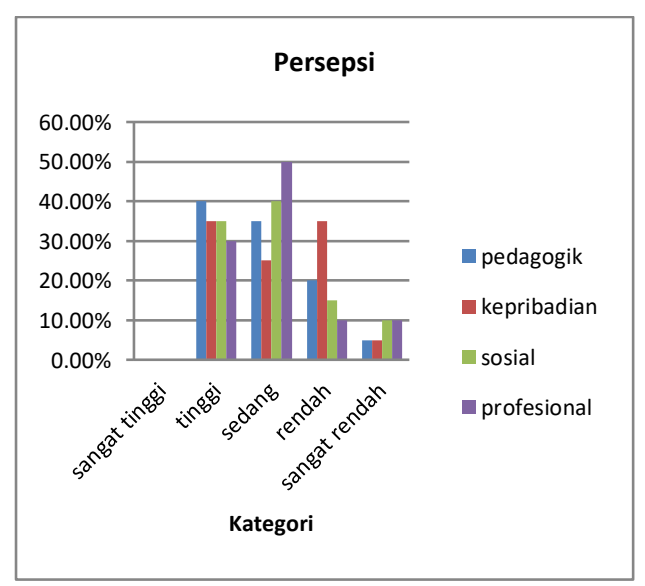

Dari gambar 6 diperoleh persepsi guru penjas terhadap Kompetensi Mahasiswa Magang 2 Program Studi Penjas FKIP UNIB di SMP Negeri Kota Bengkulu tahun 2018 yaitu kategori sangat tinggi, 0 kompetensi (0\%) dalam tinggi, kompetensi pedagogik (40\%), kompetensi kepribadian ( 35\%), kompetensi sosial (35\%) kompetensi profesional (30\%). Dalam kategori sedang, kompetensi pedagogik (35\%), kompetensi kepribadian (25\%), kompetensi sosial (40\%) kompetensi profesional (50\%). Dalam kategori rendah, kompetensi pedagogik (20\%), kompetensi kepribadian ( $35 \%$ ), kompetensi sosial (15\%) kompetensi profesional (10\%), dalam kategori sangat rendah di kompetensi pedagogik (5\%), kompetensi kepribadian ( 5\%), kompetensi sosial (10\%) kompetensi profesional (10\%). Dengan demikian persepsi guru penjas terhadap Kompetensi Mahasiswa Magang 2 Program Studi Penjas FKIP UNIB di SMP Negeri Kota Bengkulu tahun 2018 adalah sedang.

\section{PEMBAHASAN}

Menurut UU No. 14 tahun 2005 pasal 8 menyatakan guru wajib memiliki kualifikasi akademik, kompetensi, sertifikat pendidik, sehat jasmani dan rohani, serta memiliki kemampuan untuk mewujudkan tujuan pendidikan nasional. Selanjutnya pasal 10 ayat 1 mengatakan kompetensi guru sebagai mana dimaksud dalam pasal 8 meliputi kompetensi pedagogik, kompetensi sosial, kompetensi kepribadian dan kompetensi 
profesional yang diperoleh melalui pendidikan profesi.

Berdasarkan hasil penelitian menunjukkan bahwa diperoleh persepsi guru penjas terhadap Kompetensi Mahasiswa Magang 2 Program Studi Penjas FKIP UNIB di SMP Negeri Kota Bengkulu tahun 2018 yaitu sebanyak 3 guru (15\%) dalam kategori sangat rendah, 3 guru (15\%) dalam kategori rendah, 7 guru (35\%) dalam kategori sedang, 5 guru (25\%) dalam kategori, dan 2 guru (10\%) dalam kategori sangat tinggi. Frekuensi terbanyak sebesar 35,\%, yaitu pada kategori sedang. Dengan demikian persepsi guru penjas terhadap Kompetensi Mahasiswa Magang 2 Program Studi Penjas FKIP UNIB di SMP Negeri Kota Bengkulu tahun 2018 adalah sedang. Dari empat kompetensi tersebut kompetensi pedagogik memiliki kategori yang sangat tinggi, ini karena mahasiswa penjas selalu mendapatkan perkembangan terbaru. kompetensi profesional dalam kategori sedang terbanyak. Ini dikarenakan mahasiswa masih dalam tahap belajar untuk menjadi guru profesional. Kompetensi sosial juga mendapat kategori sedang dan di ikuti kategori tinggi itu artinya mahasiswa mampu berkomunikasi dan bersosial dengan baik. Hanya saja pada kompetensi kepribadian yang memperoleh kategori rendah dan tinggi. Itu artinya sebagian mahasiswa mempunyai kepribadian yang kurang baik.

Pada kompetensi pedagogik, menurut Janawi (2012 : 65) mengatakan kompetensi pedagogik adalah kemampuan guru berkenaan dengan penguasaan teoritis dan proses aplikasinya dalam pembelajaran. Berdasarkan hasil penelitian diperoleh sebanyak 1 guru (5\%) dalam kategori sangat rendah, 4 guru (20\%) dalam kategori rendah, 7 guru (35\%) dalam kategori sedang, 8 guru (40\%) dalam kategori tinggi, dan 0 guru $(00 \%)$ dalam kategori sangat tinggi. Frekuensi terbanyak sebesar $40 \%$, yaitu pada kategori tinggi, kompetensi pedagogik yang meliputi indikator memahami peserta didik secara mendalam, merancang pembelajaran termasuk memahami landasan pendidikan untuk kepentingan pembelajaran, melaksanakan pembelajaran, merancang dan melaksanakan evaluasi pembelajaran dan mengembangkan peserta didik untuk mengaktualisasikan berbagai potensi memperoleh kategori tinggi.

Kepribadian menurut Daradjat dalam Syiful Sagala (2009: 33) disebut sebagai sesuatu yang abstrak, sukar dilihat secara nyata, hanya dapat diketahui lewat penampilan, tindakan, dan ucapan ketika menghadapi persoalan, atau melalui atsarnya saja. Berdasarkan hasil penelitian pada kompetensi kepribadian, diperoleh sebanyak 1 guru (5\%) dalam kategori sangat rendah, 7 guru (20\%) dalam kategori rendah, 5 guru (35\%) dalam kategori sedang, 7 guru (35\%) dalam kategori tinggi, dan 0 guru (00\%) dalam kategori sangat tinggi. Frekuensi terbanyak sebesar 35,\%, yaitu pada kategori rendah dan tinggi. Dengan kesimpulan ini maka mahasiswa telah 
memiliki kepribadian yang positif dan mencerminkan seorang guru yang baik ketika melaksanakan PPL

Pada kompetensi sosial, diperoleh sebanyak 2 guru (10\%) mempunyai persepsi sangat rendah, 3 guru (15\%) dalam kategori rendah, 8 guru $(40 \%)$ dalam kategori sedang, 7 guru (35\%) dalam kategori tinggi, dan 0 guru $(00 \%)$ dalam kategori sangat tinggi. Frekuensi terbanyak sebesar 40,\%, yaitu pada kategori sedang. kompetensi sosial yang meliputi indikator mampu berkomunikasi dan bergaul secara efektif dengan peserta didik, dan mampu berkomunikasi dan bergaul secara efektif dengan pendidik dan tenaga kependidikan memperoleh kategori sedang. Menurut Dian Pujianto (2014) kompetensi sosial sangat diperlukan dalam proses belajar mengajar dan dalam kehidupan sehari-hari seorang guru.

Menurut Mulyasa (2008: 135), kompetensi profesional adalah penguasaan materi pembelajaran secara luas dan mendalam yang memungkinkan membimbing peserta didik memenuhi standar kompetensi yang Standar Pendidikan Nasional. Hasil penelitian yang dilakukan pada kompetensi profesional, diperoleh sebanyak 2 guru (10\%) dalam kategori sangat rendah, 2 guru (10\%) dalam kategori rendah, 10 guru (50\%) dalam kategori sedang, 6 guru (30\%) dalam kategori tinggi, dan 0 guru (00\%) dalam kategori sangat tinggi. Frekuensi terbanyak sebesar 50\%, yaitu pada kategori sedang. kompetensi profesional yang meliputi indikator menguasai substansi keilmuan yang terkait dengan bidang studi dan menguasai struktur dan metode keilmuan memperoleh kategori sedang.

Setelah kita lihat dari masingmasing kompetensi, faktor kompetensi pedagogik memperoleh persepsi pada kategori sedang, kompetensi kepribadian memperoleh persepsi pada kategori rendah dan tinggi, kompetensi sosial memperoleh persepsi pada ketegori sedang dan kompetensi profesional memperoleh persepsi pada kategori sedang. Memperhatikan hal ini, tampak jelas bahwa persepsi guru penjas terhadap Kompetensi Mahasiswa Magang 2 Program Studi Penjas FKIP UNIB di SMP Negeri Kota Bengkulu tahun 2018 secara garis besar adalah sedang. Hanya pada kompetensi kepribadian saja yang memperoleh kategori rendah dan tinggi. Tentu hasil ini menjadi bahan pertimbangan bagi universitas untuk meningkatkan kompetensi kepribadian mahasiswa agar benarbenar siap terjun di lapangan. Namun secara keeluruhan persepsi guru penjas terhadap Kompetensi Mahasiswa Magang 2 Program Studi Penjas FKIP UNIB di SMP Negeri Kota Bengkulu tahun 2018 adalah sedang.

\section{PENUTUP}

\section{SIMPULAN DAN SARAN}

Berdasarkan hasil analisis data menunjukkan bahwa persepsi guru penjas terhadap Kompetensi Mahasiswa Magang 2 Program Studi Penjas FKIP UNIB di SMP Negeri Kota Bengkulu tahun 2018 yaitu (a) kompetensi pedagogik dalam 
kategori tinggi, (b) kompetensi kepribadian dalam kategori tinggi dan rendah, (c) kompetensi sosial dalam kategori sedang, (d) kompetensi Profesional dalam kategori sedang. Secara keseluruhan masuk dalam kategori sedang yakni sebesar 35\%. Sedangkan sisanya yakni $15 \%$ masuk dalam kategori sangat rendah, $15 \%$ masuk dalam kategori rendah, 25\% masuk dalam kategori tinggi, $10 \%$ masuk dalam kategori sangat tinggi.

Sehubungan dengan hasil penelitian tentang Persepsi Guru Penjas terhadap Kompetensi Mahasiswa Magang 2 Program Studi Penjas FKIP UNIB di SMP Negeri Kota Bengkulu tahun 2018, peneliti mengajukan saran-saran sebagai berikut:

1. Untuk UNIB khususnya Prodi Penjas dan Unit PPL sebagai badan yang mengurus serta menyelenggarakan program magang 2/PPL agar menambah intensitasnya dalam mengontrol/menyidak mahasiswa magang 2/PPL di sekolah dimana mahasiswa menjalankan Program magang 2/PPL tujuannya agar mahasiswa lebih terawasi dan agar kinerjanya sesuai dengan yang ditentukan UNIB.

2. Untuk guru penjas, hendaknya lebih terbuka dan lebih tegas dalam membimbing mahasiswa magnag 2/PPL, artinya jika memang terjadi kesalahan atau tidak sesuai dari kinerja mahasiawa PPL bisa langsung diluruskan, atau jika perlu dikomunikasikan kepada UNIB selaku badan yang mengirimnya. Dengan demikian diharapkan kegiatan magang 2/PPL yang akan datang lebih baik.

3. Untuk teman-teman mahasiswa diharapkan mendalami semua materi yang diberikan pada perkuliahan agar bisa diterapkan pada saat PPL ataupun saat mengajar sebagai guru yang sebenarnya kelak.

\section{DAFTAR PUSTAKA}

Janawi. 2012. Kompetensi Guru Citra Guru Profesional. Bandung: Alfabeta.

M. Uzer Usman. 2002. Menjadi Guru Profesional. Bandung: Remaja Rosdakarya.

Mulyasa. E. 2002. Kurikulum Berbasis Kompetensi. Bandung: Remaja Rosdakarya.

Pujianto, Dian. 2014. Pemetaan Profil Dan Kompetensi Guru Pendidikan Jasmani Dan Kesehatan Tingkat Sekolah Dasar Di Kota Bengkulu. Jurnal Pendidikan Jasmani, vol.10 (1) hal. 34

Qoqoazroqu, 2013. Undang-undang tahun 2005 tentang. Diunduh pada tanggal 3 januari 2019 dari

http://qoqoazroqu.blogspot.c o.id/2013/01/undangundang-no-14-tahun-2005tentang.html?m-1.

Sagala, S. 2009. Kemampuan Profesional Guru dan 
Tenaga Kependidikan.

Bandung: Alfabeta.

Suharsimi Arikunto. 2002. Prosedur

Penelitian Suatu Pendekatan

Praktik. Jakarta: Rineka

Cipta.

2010. Prosedur Penelitian

Suatu Pendekatan Praktik.

Jakarta: PT. Rineka Cipta

Sukma, I 2005. UU no 14 tahun 2005 tentang guru dan dosen. Diunduh pada tanggal 6 januari 2019 dari http://www.slideshare.net/m obile/iwansukma/uu-no-14tahun-2005-tentang-gurudan-dosen.

Sugiyono. 2013. Metodologi

Penelitian Kombinasi (Mixed Methods). Bandung:

Alfabeta.

2016. Metode Penelitian

Kuantitatif, Kualitatif, dan

$R \& D$. Bandung: Alfabeta

Tim Penyusun Panduan magang II

UNIB. 2018. Panduan

Magang II. Bengkulu:

UNIB. 